DOI 10.4467/2543733XSSB.20.001.12192

\author{
ROMAN KOCHNOWSKI
}

Uniwersytet Pedagogiczny w Krakowie

\title{
FLOTA AUSTRIACKA 1382-1918
}

\author{
The Austrian fleet 1382-1918
}

Summary

The Habsburg fleet existing since the 14th century was finally dissolved after the fall of the Habsburg monarchy. Throughout its history, it has been an effective weapon in the fight for dominion at sea. She had several impressive victories in naval battles. Lepanto in 1571 and Lissa in 1866 can be mentioned in first order. The victorious commander in these battles Prince Juan d'Austria and Admiral Tegetthoff are widely known in the history of naval conflicts. The Austrian fleet was not defeated in battle. It was dissolved because the state, the flag of which it wore, ceased to exist.

Keywords: Adriatic, Austria, tsarist and royal fleet, the Habsburgs, navy, sea, ships

Słowa kluczowe: Adriatyk, Austria, cesarska i królewska flota, Habsburgowie, marynarka wojenna, morze, okręty

Autor nie ma wątpliwości, że sam tytuł artykułu wzbudzi u niejednego z czytelników zdumienie i zrodzi pytanie - czy Austria faktycznie miała flotę? A może autor pomylił się i zamierzał pisać o flocie australijskiej? ${ }^{1}$ A jednak pomyłka nie wchodzi w grę. Wattpliwości - co zrozumiałe - mogą jednak dotyczyć predykatu w tytule. Być może, powinno się mówić raczej o armii, a tym samym o ,flocie Habsburgów”, tak jak mówimy np. - i słusznie - o armii habsburskiej, a nie austriackiej - co najmniej do ery wojen napoleońskich ${ }^{2}$. Monarchowie z tej dynastii do końca XIX stulecia zawsze mówili o „mojej”, a nie austriackiej armii - w domyśle także flocie. Jednak na potrzeby niniejszego artykułu autor zdecy-

${ }^{1}$ Autor syntezy tego tematu już na stronie tytułowej zastrzega, że nie chodzi o flotę australijską: W. M. Donko, A Brief History of the Austrian Navy, Berlin 2012.

${ }^{2}$ Zwracają na to uwagę czescy autorzy w swym monumentalnym dziele: Pod cisařskym praporem. Historie habsburske armady 1526-1918, J.Pernes a kolektiv, Praha 2003, s. 7. 
dował się przyjać predykat ,austriacki”, będąc świadomym pewnego uproszczenia, jakiego się dopuszcza.

W dobie średniowiecza poszczególne monarchie w Europie Zachodniej (angielskiej nie wyłączając) stałej floty nie miały. Dogorywające Cesarstwo Bizantyjskie wprost przeciwnie, niemal po kres swego istnienia dysponowało znacznymi siłami morskimi, podobnie jak miejskie republiki włoskie, a zwłaszcza Wenecja. Poszczególni władcy europejscy w razie konieczności organizowali flotę, wynajmując po prostu morskich rozbójników, zwanych elegancko kaprami od listów kaperskich, które były swego rodzaju glejtem pozwalającym odróżnić ich od zwykłych piratów. Podobnie jak to ma miejsce współcześnie, utrzymywanie własnej marynarki wojennej było niezwykle kosztowne i tego rodzaju wyspecjalizowane siły poważnie obciążały budżet monarchii czy bogatych miast nadmorskich północnej części kontynentu, które wspólnymi siłami jako Związek Hanzeatycki mogły sobie pozwolić na luksus posiadania własnej floty ${ }^{3}$. Arcyksiążę austriacki Leopold III, chcąc uniknąc wysokich kosztów związanych z handlem zamorskim, a prowadzonego za pośrednictwem Wenecji, w 1382 roku włączył do swego państwa miasto i port w Trieście. Odbyło się to z pełną aprobatą jego mieszkańców, którzy dzięki temu posunięciu spodziewali się uzyskać protekcję, ale także skuteczną ochronę przed zakusami Wenecjan. Parę jednostek strażniczych tego grodu, które podniosły złoto-czarne bandery, można uznać za zaczątek floty austriackiej. Nowi poddani Wiednia nie rozczarowali się tą protekcją - Triest do 1918 roku pozostał głównym portem monarchii, a samo miasto należało do grona największych jej metropolii, podlegając niezależnie od zawirowań historycznych nieustannemu rozwojowi ${ }^{4}$.

Jakkolwiek w wyprawie Magellana uczestniczyli niemal wyłącznie Hiszpanie i garstka Portugalczyków oraz Włochów, to jednak fakt, że do niej doszło, był zasługą młodego cesarza Karola V Habsburga. Za jego panowania powstało pierwsze imperium morskie, jakim niewątpliwie była wówczas Hiszpania. Habsburgowie byli zatem pierwszą dynastia, która doceniła znaczenie handlu morskiego i posiadania kolonii, a nad ich imperium - rozciaggającym się od Balatonu przez Austrię, Niderlandy Hiszpańskie, większość Ameryki Południowej oraz Filipin - słońce nigdy nie zachodziło.

Nieślubny syn cesarza Karola V - książę Juan de Austria 7 października 1571 roku jako dowódca chrześcijańskiej floty rozgromił potęgę morską imperium osmańskiego w bitwie pod Lepanto ${ }^{5}$. Gdyby nie przedwczesna śmierć, dowodziłby zapewne Wielką Armadą w 1588 roku, i można tylko zgadywać, jak potoczyłyby się losy Anglii, imperium habsburskiego i świata, gdyby Francis Drake właśnie w nim miał swego rywala.

Po rozpadzie jedności habsburskiego imperium jego austriacka część powoływała flotę wojenną tylko w razie naglącej potrzeby. Miało to miejsce zarówno podczas wojny trzydziestoletniej, jak i zmagań z Turcją w latach 1660-1686. W pierwszym z przywołanych konfliktów korzystano z usług kaprów bałtyckich, w drugim - po raz pierwszy powołano do życia Flotyllę Dunajską, która najpierw ewakuowała skarb cesarski z zagrożonego oblężeniem Wiednia do Linzu, a następnie uczestniczyła w rekonkwiście na Węgrzech ${ }^{6}$.

\footnotetext{
${ }^{3}$ H. Pfeiffer, Seemacht Deutschland. Die Hanse, Kaiser Wilhelm II. und der neue Maritime Komplex, Berlin 2009, s. 56-60.

${ }^{4}$ W. M. Donko, A Brief History..., s. 8-9.

${ }^{5}$ H. Neuhold, Österreichs Helden zur See, Wien- Graz-Klagenfurt 2010, s. 11-22.

${ }^{6}$ R. Kochnowski, Flotylla Dunajska c. i k. marynarki, [w:] Zapomniane bandery. Flotylle rzeczne II Rzeczypospolitej, red. S. Januszewski, Wrocław 2019.
} 
Cesarz Karol VI - w obliczu kolejnych wojen z chylącym się ku upadkowi Imperium Osmańskim - powołał do życia bazującą w Trieście eskadrę trzech okrętów, obsadzonych przez załogi złożone głównie z Hiszpanów i Włochów. Dzieło to - pomimo licznych trudności kontynuowała jego córka i następczyni, cesarzowa Maria Teresa, która rozważała nawet możliwość podjęcia ekspansji kolonialnej. Jednak mocno usadowione w Europie Środkowej państwo Habsburgów nie podjęło jej, pozostając mocarstwem typowo lądowym? Następcy Marii Teresy - Józef II i Leopold II przejawiali pewne ambicje morskie, ale wojny napoleońskie siłą rzeczy skierowały uwagę domu panującego w zupełnie innym kierunku. Jednak nawet w tych trudnych dla monarchii czasach na interesującym nas polu zaszły pewne istotne zmiany - wchłonięcie Wenecji przez monarchię habsburską w 1797 roku umocniło jej pozycję nad Adriatykiem. Młodszy brat kolejnego cesarza Franciszka I, arcyksiążę Karol (znany jako naczelny dowódca armii, która pokonała Napoleona pod Aspern w 1809 roku) był pierwszym w dziejach austriackiej floty ministrem marynarki. Dzięki jego staraniom przysposobiono do dalszej służby kilka byłych okrętów floty weneckiej oraz zbudowano 8 nowych fregat. Dwie spośród nich, Austria i Augusta, odbyły dalekie rejsy oceaniczne, zawijając w 1817 roku do portów brazylijskich ${ }^{8}$. W 1804 roku powołano w Trieście - w sposób formalny - do życia Cesarsko-Królewską Marynarkę Wojenną (niem. Kaiserlich-Königliche Marine), na czele której stanął wspomniany wyżej brat cesarza. Flota zwalczała na Morzu Śródziemnym resztki piractwa oraz handel niewolnikami. Podczas Wiosny Ludów na polecenie feldmarszałka Josepha Radetzky’ego działa okrętowe ostrzelały weneckich rewolucjonistów. W roku następnym nowy dowódca floty, energiczny kontradmirał Hans-Birch von Dahlenrup przystąpił do budowy nowej bazy austriackiej marynarki w Puli, na południowym krańcu półwyspu Istria. Wysunięty głęboko w morze port miał doskonałe położenie strategiczne względem Półwyspu Apenińskiego, na którym rosnące w siłę Królestwo Piemontu i Sardynii coraz bardziej zagrażało interesom Wiednia.

We flocie wprowadzono od 1850 roku niemiecki (w miejsce włoskiego) język komendy, ujednolicono pod tym kątem nazwy okrętów i budowano nowe jednostki, np. słynną z późniejszego rejsu dookoła świata fregatę SMS Novara. (Prefiks SMS oznaczał Seiner Majestät Schiff - Okręt Jego Cesarskiej Mości). W 1854 roku dowodzenie flotą przejął zaledwie 22-letni brat cesarza Franciszka Józefa, Ferdynand Maksymilian, który, będąc marynarzem z powołania, okazał się bardzo zdolnym oficerem morskim. Skutecznie zabiegał o budowę nowych okrętów, wspierał kariery młodszych dowódców, w tym słynnego później admirała Wilhelma von Tegetthoffa, który w 1866 roku rozgromił flotę zjednoczonych Włoch w bitwie pod Lissą 9

Franciszek Józef sprawami floty nie interesował się prawie zupełnie. Jego awersję do spraw morskich pogłębiła podróż na uroczystość otwarcia Kanału Sueskiego, podczas której nieopodal Hajfy omal nie utonął z powodu katastrofy małego barkasu, przewożącego monarchę z jachtu Greif na stały ląd. Od tej pory cesarz z rzadka pokazywał się na okrętach floty i nigdy nie przywdział marynarskiego uniformu. Na pytanie niemieckiego cesarza Wilhelma II o przyczynę takiego zachowania Franciszek Józef miał powiedzieć

\footnotetext{
${ }^{7}$ A. T. Mahan, Wplyw potęi morskiej na historię 1660-1783, t. I, Oświęcim 2013, s. 191 i nast.

${ }^{8}$ W. M. Donko, A Brief History..., s. 14-17.

${ }^{9}$ P. Olender, Lissa 1866, Warszawa 2010, s. 81 i nast.
} 
z godną odnotowania skromnością że nie jest godzien nosić munduru formacji, na której się po prostu (w przeciwieństwie do swego rozmówcy) nie zna ${ }^{10}$. Ta godna pochwały szczerość monarchy miała swoje dobre strony. Cesarz nigdy nie wtrącał się w sprawy floty, pozostawiając te kwestie fachowcom z prawdziwego zdarzenia. Dlatego w przeciwieństwie do sił lądowych dualistycznej od 1867 roku monarchii jej marynarka wojenna zawsze wyróżniała się in plus na tle armii. Jej oficerowie prezentowali nieporównywalnie wyższy poziom intelektualny w porównaniu z kolegami reprezentującymi piechotę czy kawalerię. Kandydat na oficera floty musiał przejść niełatwy test $\mathrm{z}$ wiedzy ogólnej oraz wymagający sprawdzian kondycji fizycznej, nim dopuszczono go do grona kadetów Akademii Morskiej we Fiume. Co więcej - na żadną protekcję kandydaci na cesarskich i królewskich wilków morskich liczyć nie mogli. Sam cesarz żartował, że jego władza kończy się na bramie arsenału morskiego w Puli. Warto wspomnieć, że Franciszek Józef, choć do swego dyletantyzmu w sprawach morskich otwarcie się przyznawał, miał hojną rękę, gdy idzie o dalekomorskie rejsy swych okrętów i ,prezentowanie bandery”, a w gronie jego adiutantów zawsze znajdował się przynajmniej jeden oficer floty ${ }^{11}$.

Spory wokół kształtu sił zbrojnych Austro-Węgier (Madziarzy domagali się odrębnej armii nie tylko na poziomie obrony terytorialnej, ale i wojsk operacyjnych) opóźniły sprawę wyodrębnienia floty, co postulował admirał Tegetthoff. Dopiero w roku 1868 wydzielono w ministerstwie wojny sekcję marynarki, na czele której stanął zwycięzca spod Lissy. Niestety, ten powszechnie szanowany oficer flagowy zmarł w niespełna trzy lata później w wieku zaledwie 43 lat. Po jego śmierci dynamika rozwoju floty uległa pewnemu wyhamowaniu. Następcy Tegetthoffa nie mieli tego autorytetu co on, a ponadto - co równie ważne - w Ministerstwie Wojny flota nie miała wtedy żadnego istotnego protektora z kręgu domu panującego ${ }^{12}$. Skutkiem takiego stanu rzeczy był zastój w rozwoju sił morskich dualistycznej monarchii w ostatnich dwu dekadach XIX stulecia. Marazm ogarnął w tym czasie całość sił zbrojnych Austro-Węgier. Wynikało to w pewnej mierze z ówczesnej sytuacji międzynarodowej. Po kongresie berlińskim 1878 roku sytuacja militarno-polityczna w Europie była nader stabilna. Kłopoty ze zrównoważeniem finansów publicznych monarchii habsburskiej prowadziły do cięć w wydatkach na obronność. Armia i flota starzały się wraz z cesarzem. Marazm w rozwoju floty cesarskiej i królewskiej (od 1867 roku) przezwyciężony został dopiero u schyłku XIX stulecia, gdy zmarłego w tragicznych okolicznościach następcę tronu, arcyksięcia Rudolfa zastąpił bratanek cesarza, arcyksiążę Franciszek Ferdynand, oficer morski z wykształcenia i prawdziwy pasjonat floty ${ }^{13}$. W jego osobie flota znalazła potężnego obrońcę i protektora. Cesarz, który ze swym bratankiem w bardzo wielu kwestiach się nie zgadzał, gdy idzie o kwestie wojennomorskie, darzył go pełnym zaufaniem, co miało niewątpliwie pozytywny wpływ na jej kondycję na przełomie XIX i XX stulecia. Było to istotne w kontekście morskiego wyścigu zbrojeń, który u progu XX stulecia zapoczątkowany został brytyjsko-niemiecką rywalizacją na tym polu. Do tego współzawodnictwa przystąiły także mniejsze państwa z ambicjami morskimi, jak np. Włochy, które - pomimo że formalnie związane były sojuszem Trójprzymierza z Rze-

\footnotetext{
${ }^{10}$ Ch. Schmetterer, Kaiser Franz Joseph I, Wien-Köln-Weimar 2016, s. 105-106.

${ }^{11}$ B. Nowotny, Wspomnienia, Gdańsk 2006, s. XVI.

${ }^{12}$ U. Schöndorfer, Wilhelm von Tegetthoff, Wien 1958, s. 73.

${ }^{13}$ F. Weissensteiner, Franz Ferdinand. Der verhinderte Herrscher, Wien 2007, s. 74.
} 
szą i monarchią habsburską, postrzegano w c. i k. admiralicji jako rywala na Adriatyku. Zaproponowany przez Franciszka Ferdynanda na dowódcę floty admirał Hermann von Spaun, pełniący tę funkcję od 1897 roku, okazał się niestrudzonym orędownikiem przebudowy i rozbudowy marynarki spod czerwono-biało-czerwonej bandery. Za jego kadencji siły morskie Austro-Węgier zasiliły nowoczesne pancerniki typu Habsburg, systematycznie i proporcjonalnie rozwijano też flotylle mniejszych okrętów. W 1904 roku między nim a ówczesnym ministrem wojny, generałem Heinrichem von Pitreichem, doszło do ostrego sporu na tle finansowania zbrojeń morskich, w wyniku którego admirał podał się do dymisji. Nie wycofał jej mimo nalegań monarchy. Postawa admirała von Spauna tak dalece zaimponowała cesarzowi Franciszkowi Józefowi (większość austriackich generałów trzymała się kurczowo stanowisk do późnej starości), że przyjmując jego dymisję, nakazał, by nowo budowanemu szybkiemu krążownikowi nadać imię von Spauna. Krążownik Admiral Spaun był jedynym austriackim okrętem, który otrzymał nazwę żyjącego oficera flagowego floty (wyjątkiem były osoby należące do rodziny domu panującego) ${ }^{14}$.

Następca von Spauna, wiceadmirał hrabia Rudolf Montecuccoli, a później admirał Anton Haus kontynuowali dzieło poprzednika. Systematycznie wymieniano przestarzałe okręty na nowe. Austriaccy konstruktorzy pilnie i dogłębnie studiowali doświadczenia z wojny japońsko-rosyjskiej oraz zapoznawali się z najświeższymi nowinkami techniki okrętowej, zwłaszcza pancernikami typu drednot. Prawdziwą rewolucją w konstrukcji dużych jednostek floty Austro-Węgier były okręty liniowe typu Tegetthoff. Dowództwo floty świadome faktu, że będące w służbie jednostki ustępują znacznie okrętom obcych bander, zaprojektowało nowe liniowce niezwykle starannie. Trójlufowe wieże artylerii głównej, wyprodukowane w pilźnieńskich zakładach Skoda, jako prekursorska konstrukcja - stanowiły absolutną nowość. Artyleria główna tych okrętów została rozmieszczona w tzw. superpozycji - na dziobie i rufie po dwie wieże, co oznaczało, że mogły one prowadzić ogień ze wszystkich dział artylerii głównej na jedną burtę. Były one stosunkowo niskimi okrętami, a ich sylwetki przypominały nieco wyrośnięte statki wycieczkowe znad Balatonu, ale fakt ten w niczym nie umniejszał ich bardzo dużego potencjału bojowego. Gdy pierwszy z nich wchodził w 1912 roku do służby, należał niewątpliwie do najlepszych jednostek swej klasy ${ }^{15}$. Admirał Anton Haus dbał o równomierny rozwój c. i k. floty, którą w przededniu I wojny światowej zasilały kolejne szybkie krążowniki, torpedowce oraz okręty podwodne. Systematycznie rozbudowywano także zaplecze logistyczne w Puli, Trieście oraz Kotorze. W obliczu narastających napięć politycznych w Europie u progu drugiej dekady XX stulecia admirał Haus opracował plany działań c. i k. marynarki na wypadek wojny. Admiralicja austriacka liczyła się z faktem znacznej przewagi potencjalnego przeciwnika, za jakiego uchodziła francuska Marine Nationale, wzmocniona obecnością solidnego zespołu śródziemnomorskiego Royal Navy. W obliczu - jak zakładano - znacznej przewagi przeciwnika działania prowadzić miały głównie siły lekkie. Przy czym - według założeń admirała Hausa, w działaniach obronnych miały dominować torpedowce oraz broń minowa, natomiast akcje zaczepne miały stać się domeną okrętów podwodnych.

${ }^{14}$ F. Sieche, Kreuzer und Kreuserprojekte der k.u.k. Kriegsmarine 1889-1918, Hamburg 2002, s. 104 i nast.

${ }^{15}$ W. Aichelburg, Die „, Tegetthoff”' Klasse: Österreich-Ungarns größte Schlachtschiffe, München 1981, s. 10 i nast. 
Zasadniczy trzon floty - złożony z okrętów liniowych, zwłaszcza tych najnowszej generacji - miał odegrać rolę czynnika odstraszającego (ang. Fleet in Being), co w kontekście późniejszych wydarzeń okazało się słuszną strategią ${ }^{16}$.

W 1914 roku flota dualistycznej monarchii miała w służbie 12 okrętów liniowych (w tym trzy typu drednot), 3 pancerniki obrony wybrzeża, 3 krążowniki pancerne, 4 nowoczesne szybkie krążowniki, 5 starych krążowników pancernych, 6 większych i 12 mniejszych kontrtorpedowców. Uzupełniało ją 71 torpedowców, w większości nowoczesnych, 6 okrętów podwodnych, 9 kanonierek oraz liczne okręty pomocnicze, oraz wsparcia logistycznego. W budowie znajdował się 1 drednot, 19 torpedowców oraz 5 okrętów podwodnych ${ }^{17}$. Marynarka austro-węgierska stanowiła podówczas 8 potęgę morską na świecie (po brytyjskiej, niemieckiej, amerykańskiej, japońskiej, rosyjskiej, francuskiej i włoskiej). Personel był doskonale wyszkolony i zmotywowany. Problemy narodowościowe we flocie nie miały podówczas żadnego wpływu na jej gotowość bojową. Również dlatego, że służyli w niej głównie ochotnicy, w tym znaczeniu, że poborowi sami decydowali się na służbę w jej szeregach, a poza tym w dużej mierze byli to ludzie, którzy już w życiu cywilnym byli z morzem oraz żeglugą obeznani.

Obok floty pełnomorskiej znaczną wartość bojową miała Flotylla Dunajska, stanowiąca od 1871 roku integralną część c. i k. marynarki wojennej. Jej oficerowie i marynarze byli równie dobrze wyszkoleni i zmotywowani co ich koledzy służący na Adriatyku. Przed wybuchem wojny światowej Flotylla Dunajska została znacznie wzmocniona materiałowo i kadrowo. W czerwcu 1914 roku w jej skład wchodziło 7 opancerzonych monitorów (2 dalsze znajdowały się w budowie), kilka mniejszych kanonierek i okrętów pomocniczych ${ }^{18}$. Dowodził nią w momencie wybuchu wojny komandor porucznik (wedle austro-węgierskiej nomenklatury Fregattenkapitän) Marius Peter August Ratković von Modruš. Okręty tej właśnie flotylli, mianowicie monitory Temes, Bodrog oraz Samos, rozpoczęły dnia 29 lipca 1914 roku wojnę z Serbią, ostrzeliwując Belgrad we wczesnych godzinach porannych. Wkrótce konflikt ten zamienił się w światową pożogę. Dla cesarskiej i królewskiej floty była to - jak się okazało - ostatnia wojna. Flota pełnomorska zgrupowana w Puli i Kotorze mogła spokojnie dokończyć mobilizację. Włochy u progu wojny zachowały bowiem neutralność. Jedynym przeciwnikiem mającym dostęp do Morza Adriatyckiego była Czarnogóra, która jednak własnej floty nie posiadała. Do blokady jej wybrzeża, przez które mogła być dostarczona pomoc materialna dla Serbii, c. i k. flota użyła lekkich sił, mianowicie małych krążowników Szegitvár i Zenta oraz kilku torpedowców. Dnia16 sierpnia drugi z nich oraz towarzyszący mu torpedowiec Ulan natknęły się na zespół okrętów liniowych Marine Nationale w towarzystwie kilku okrętów brytyjskich, łącznie 17 jednostek. Po nierównej walce austriacki krążownik poszedł na dno, natomiast torpedowiec wykonał brawurowy atak torpedowy i dopiero na wyraźne polecenie dowódcy tonącej Zenty zwiększył prędkość do maksymalnej i oddalił się od przeciwnika ${ }^{19}$.

${ }^{16}$ R. Kochnowski, Flota Austro-Wegierska w przededniu I wojny światowej, [w:] Od Port Stanley do Port Artur. Z dziejów konfliktów morskich w XX stuleciu, red. R. Kochnowski i J. Jastrzębski. Oświęcim 2016, s. 75.

${ }^{17}$ J. Gozdawa-Gołębiowski, T. Wywerka-Perkurat, Pierwsza wojna światowa na morzu, Warszawa 1994, s. $33-34$.

${ }^{18}$ R. Kochnowski, Flotylla Dunajska c. i k. marynarki, [w:] Zapomniane bandery. Flotylle rzeczne II Rzeczypospolitej, red. S. Januszewski. Wrocław 2019, s. 42-43.

${ }^{19}$ A. Samek, Flota, której już nie ma. Powstanie, rozwój i działania marynarki habsburskiej, Kraków 2011, s. 105 . 
Na szczególne wspomnienie zasługuje epopeja krążownika pancernego Kaiserin Elizabeth i jego załogi na odległych wodach Dalekiego Wschodu. Okręt ten - znajdujący się w momencie gdy Japonia wypowiedziała wojnę mocarstwom centralnym w niemieckiej kolonii Cingtao - od końca września do 2 listopada 1914 roku uczestniczył w obronie portu przed atakami armii i floty Kraju Wschodzącego Słońca. 2 listopada 1914 roku uszkodzony i osadzony na dnie redy krążownik został opuszczony przez załogę i wysadzony w powietrze. Jedyny reprezentant habsburskiej marynarki na odległych akwenach przestał istnieć ${ }^{20}$. Większość sił głównych c. i k. floty pozostawała w tym czasie w bazach. Jedynym wypadem większych okrętów była akcja pancerników Habsburg i Radetzky przeciw bateriom artylerii ciężkiej, ustawionym przez francuską marynarkę na czarnogórskim wybrzeżu. Ostatecznie, w wyniku akcji wspomnianych pancerników 21 października 1914 roku baterie te zostały zniszczone. Natomiast akcje zaczepne prowadziły na odległych od macierzystych baz akwenach austro-węgierskie okręty podwodne. 21 grudnia 1914 roku $U-12$ - dowodzony przez kapitana marynarki (według austriackiej nomenklatury Linienschiffsleutnant) - zaatakował na wysokości Valony francuski pancernik Jean Bart. Jedna $\mathrm{z}$ dwu wystrzelonych torped trafiła w dziób francuski okręt, powodując poważne uszkodzenia. Jeszcze większy sukces stał się udziałem załogi U-5 pod dowództwem legendarnego podwodnika, kapitana Georga von Trappa. Na południowym Adriatyku napotkał on 24 kwietnia 1915 r. francuski krążownik pancerny Leon Gambetta. Trafiona dwoma torpedami jednostka zatonęła wraz z dowódcą i 574 członkami załogi ${ }^{21}$. Kapitan von Trapp stał się bohaterem narodowym, fetowanym w każdym zakątku naddunajskiej monarchii. Jego sukces był tym większy, że miał on strategiczne następstwa. Marine Nationale wycofała się bowiem z wód południowego Adriatyku, co skutkowało zmniejszeniem dostaw sprzętu wojskowego via Czarnogóra dla armii serbskiej drogą morską. Jednak sukces ten nie zmieniał ogólnie trudnego strategicznego położenia floty habsburskiej, zamkniętej w adriatyckim akwenie. Przełamanie blokady cieśniny Otranto byłoby możliwe jedynie w wypadku wypełnienia przez Włochy zobowiązań wynikających z Trójprzymierza. Dnia 23 maja 1915 roku, gdy Ententa zaaprobowała wszystkie roszczenia terytorialne Rzymu wobec monarchii habsburskiej, Rzym wypowiedział Berlinowi i Wiedniowi wojnę. Tego samego dnia w morze wyszedł silny zespół floty austro-węgierskiej, w skład którego wchodziły niemal wszystkie okręty liniowe. Okręty spod czerwono-biało-czerwonej bandery ostrzelały instalacje portowe w Anconie i wycofały się do baz macierzystych bez strat własnych. W następnych dniach rajdu na włoskie porty adriatyckie dokonały okręty liniowe Radetzky i Zrinnyi oraz mniejsze jednostki z krążownikami Admiral Spaun i Helgoland na czele. Początek wojny monarchii habsburskiej z Italią ujawnił zupełne nieprzygotowanie włoskich sił zbrojnych do działań. Nie wszystko można usprawiedliwić, czy wyjaśnić, niewielkim - oględnie mówiąc, entuzjazmem wojennym włoskich żołnierzy i marynarzy. Szwankowało wyszkolenie, bardzo duże niedociągnięcia występowały w logistyce. Marynarka wojenna Austro-Węgier była pod tym względem całkowitym przeciwieństwem swojego przeciwnika z drugiego brzegu Adriatyku. Kadra zawodowa prezentowała wyso-

\footnotetext{
${ }^{20}$ K. Csonkarèti, Marynarka wojenna Austro-Węgier w I wojnie światowej 1914-1918, Kraków 2004, s. 49.

${ }^{21}$ G. von Trapp, Do ostatniego salutu banderze. Wspomnienia dowódcy austro-węgierskiego okrętu podwodnego, Gdańsk 2004, s. 20-34.
} 
ki poziom wyszkolenia, będąc mocno zmotywowaną do działań, podobnie rzecz się miała wśród szeregowych marynarzy. Nie bez znaczenia był fakt przewagi taktyczno-technicznej cesarskich i królewskich okrętów nad ich włoskimi odpowiednikami. Świadomość tych faktów we włoskim dowództwie doprowadziła do zaniechania z końcem lata 1915 roku aktywnych działań własnej floty przeciw siłom morskim Austro-Węgier. Wyjątkiem były próby podejmowane przez lekkie jednostki, ale też bez większych sukcesów.

Pod koniec roku strona austriacka podjęła próbę przełamania blokady cieśniny Otranto. W jej pobliże wysłano zespół złożony z lekkiego krążownika Helgoland w towarzystwie kilku torpedowców. W cieśninie zespół ten natknął się na trzy krazżowniki brytyjskie w towarzystwie kilkunastu francuskich i włoskich torpedowców. Dzięki taktycznym umiejętnościom dowódcy austriackiego - komandora Heinricha Seitza udało się oderwać okrętom cesarskiej i królewskiej floty od przeważających sił nieprzyjaciela, jednak nie bez strat. Utracono bowiem dwa torpedowce - Lika oraz Triglav ${ }^{22}$. Nawet gdyby Włochy zachowały neutralność, siły Royal Navy i Marine Nationale w zupełności wystarczyłyby do zblokowania wyjścia z Adriatyku na Morze Śródziemne. Flota austro-węgierska musiała ograniczyć swą aktywność do wód macierzystych oraz wybrzeża włoskiego od Bari po Wenecję. W tej sytuacji głównodowodzący habsburskiej floty, admirał Anton Haus, kontynuował strategię z początku wojny - ofensywne działania prowadziły wyłącznie siły lekkie. Okręty liniowe, nie mając widoków na starcie z trzonem sił włoskich, sporadycznie wspierały działania wojsk lądowych wzdłuż północnych wybrzeży Adriatyku. Strategia ta była właściwa. Zarówno Brytyjczycy, jak i Francuzi musieli utrzymywać na południowym Adriatyku znaczne siły, nie mając złudzeń co do wartości włoskiej Regia Marina. Co więcej, Brytyjczycy zmuszeni byli prosić o pomoc swego dalekowschodniego sojusznika - cesarską flotę japońską; Tokio wysłało na Morze Śródziemne eskadrę złożoną z kilku krążowników i torpedowców ${ }^{23}$.

Flota cesarsko-królewska była prekursorem, gdy idzie o wykorzystanie nowego rodzaju broni, jakim było lotnictwo. Już przed wojną na pancerniku SMS Radetzky zainstalowano katapultę dla wodnosamolotów. 8 lipca 1916 roku wracający z cieśniny Otranto krążownik Novara, dowodzony przez komandora Miklosa Horthy'ego, został zaatakowany przez zespół włoskich torpedowców ${ }^{24}$. Na odsiecz pospieszyły austro-węgierskie wodnosamoloty, startujące z kotwicowiska Kumbor, a ich atak zmusił do odwrotu włoski zespół. Był to jeden z pierwszych przypadków skutecznej ingerencji sił powietrznych w działania na morzu.

27 sierpnia 1916 roku Rumunia wypowiedziała wojnę mocarstwom centralnym. $\mathrm{Z}$ punktu widzenia wojny morskiej prowadzonej na Adriatyku fakt ten nie miał większego znaczenia. Natomiast zaktywizował do działania okręty Flotylli Dunajskiej, które ostrzelały rumuński port w Giurgiu nad Dunajem, niszcząc instalacje przeładunkowe oraz tamtejszą rafinerię ropy naftowej. W kilka dni po otwarciu tego nowego frontu wojny na Bałkanach większość okrętów rumuńskich na Dunaju została rozbita. Po oczyszczeniu z min rzeka ta na całej długości aż do końca wojny znalazła się we władaniu habsburskiej Flotylli Dunajskiej25.

${ }^{22}$ K. Csonkarèti, Marynarka wojenna Austro-Wegier..., s. 105-108.

${ }^{23}$ W. M. Donko, Die Kaiserliche Japanische Kriegsmarine im Mittelmeer 1917-1919. Die Geschichte des 2. Sondergeschwaders unter admiral Sato, Berlin 2014, s. 15 i nast.

${ }^{24}$ T. Sakmyster, Miklos Horthy, Wien 2006, s. 19.

${ }^{25}$ R. Kochnowski, Flotylla Dunajska..., s. 48. 
Ogłoszenie przez Rzeszę Niemiecką nieograniczonej wojny podwodnej przyjęto w Wiedniu z mieszanymi uczuciami. Następca (od 20 listopada 1916 roku) sędziwego Franciszka Józefa, młody cesarz Karol I, skłaniający się ku poszukiwaniu kompromisowego pokoju z Ententą, świadom był, że tego rodzaju działania utrudnią, a może nawet uniemożliwią te wysiłki. Dowódca floty Anton Haus, podniesiony w poprzednim roku do rangi wielkiego admirała (niem. Großadmiral), uważał wprawdzie, że traktaty międzynarodowe nie są nienaruszalnymi dogmatami, ale w zaistniałej sytuacji deklaracja nieograniczonej wojny podwodnej może narazić mocarstwa centralne na katastrofalny w skutkach konflikt z USA, co okazało się prorocze, choć los oszczędził mu dożycia tego dnia. 8 lutego 1917 roku po krótkiej chorobie admirał Haus zmarł w wieku 65 lat na pokładzie swego flagowego okrętu Viribus Unitis $^{26}$. Jego następcą został Chorwat z pochodzenia, wiceadmirał Maximilian Njegovan.

W pierwszej połowie 1917 roku intensywność działań na morzu nieco osłabła. Sporadycznie okręty cesarskie i królewskie wspierały własne oddziały lądowe, nie napotykając na włoską Regia Marina. Późną wiosną 1917 roku admirał Njegovan i jego sztab zdecydowali o podjęciu akcji zaczepnej w cieśninie Otranto przeciw trawlerom blokady. Do akcji wyznaczono szybkie lekkie krążowniki Helgoland, Novarę oraz Saidę - w towarzystwie 2 kontrtorpedowców Balaton i Csepel. Operacją kierował dowódca Novary, komandor Miklos Horthy. Po drodze w nocy z 14 na 15 maja 1917 roku w kierunku cieśniny Otranto zespół napotkał włoski konwój złożony z trzech niewielkich statków w eskorcie torpedowca Borea. Oba austro-węgierskie kontrtorpedowce po krótkiej walce zatopiły wszystkie statki oraz okręt eskorty. Jednostki włoskie nie zdążyły nadać sygnału o napotkaniu sił nieprzyjacielskich, toteż zaskoczenie wśród załóg trawlerów blokady było ogromne. 14 spośród nich zostało zniszczonych praktycznie bez strat własnych. Zaalarmowane dowództwo włoskie wysłało przeciw zespołowi komandora Horthy’ego silny zespół, złożony z dwu lekkich krążowników brytyjskich Dartmouth i Bristol w towarzystwie pięciu włoskich torpedowców. Okręty Royal Navy wyposażone były w działa kalibru152 mm, co dawało im znaczną przewagę wobec austriackich krążowników, których artyleria główna miała kaliber zaledwie $100 \mathrm{~mm}$. Mimo to komandor Horthy, choć jego okręty dysponowały przewagą prędkości, podjął walkę. W jej trakcie uszkodzenia odniosły Helgoland oraz Novara, na pokładzie której poważnie ranny został komandor Horthy. W krytycznej dla austro-węgierskiej eskadry sytuacji na akwenie walki pojawił się krążownik pancerny SMS Sankt Georg, którego działa kalibru $240 \mathrm{~mm}$ celnym ogniem zmusiły do odwrotu brytyjskie okręty. W drodze powrotnej do bazy w Tarencie krążownik Dartmouth został zatopiony torpedami niemieckiego okrętu podwodnego UC 25. Bitwa ta wykazała świetne wyszkolenie i wysoki poziom morale załóg okrętów c. i k. floty, które podjęły skuteczną walkę z wysoce renomowanym przeciwnikiem, jakim była Royal Navy. Nad Dunajem Miklos Horthy stał się bohaterem narodowym, otrzymując najwyższe odznaczenie wojskowe monarchii - Order Św. Teresy ${ }^{27}$.

Z końcem 1917 roku flota włoska, która do tej pory nie odniosła żadnych godnych odnotowania sukcesów, użyła nowej broni w zmaganiach na Adriatyku. W nocy z 9 na 10 grudnia 1917 roku do portu wojennego w Trieście wdarły się dwa miniaturowe ścigacze torpedowe $M A S 13$ i MAS 15 pod włoską banderą. Zaatakowały one torpedami dwa stare pancerniki: Budapest oraz Wien. Drugi z okrętów, trafiony dwiema torpedami, zatonął

\footnotetext{
${ }^{26}$ P. G. Halpern, Anton Haus. Österreich - Ungarn Großadmiral, Graz 1998, s. 330-331.

${ }^{27}$ T. Sakmyster, Miklos Horthy..., s. 20-21.
} 
w ciagu zaledwie paru minut. Zaskoczenie po stronie austro-węgierskiej było duże, a obu włoskim okrętom udało się ujść bez strat ${ }^{28}$. Flocie habsburskiej przybył groźny przeciwnik. Niebezpieczny tym bardziej, że załoga tych małych okręcików - tworzących flotyllę ścigaczy pod dowództwem komandora hrabiego Luigi Rizzo - złożona była wyłącznie z ochotników i na tle innych marynarzy Regia Marina wyróżniała się wysokimi poziomem nie tylko wyszkolenia, ale i morale.

Obalenie caratu w Rosji, a następnie przejęcie w tym kraju władzy przez bolszewików, nie pozostało bez wpływu na sytuację wewnętrzną państw centralnych. Nastroje polityczne uległy zdecydowanej radykalizacji, a blokada stosowana przez państwa Ententy i głód będący jej następstwem sprzyjały im w znaczny sposób. Zwycięski dla Berlina i Wiednia pokój brzeski sytuację tę zmieniły w nieznaczny sposób. Jednak zanim do niego doszło, w c. i k. flocie wybuchł 1 lutego 1918 roku otwarty bunt. Na stacjonowanym w Kotorze krążowniku pancernym Sankt Georg załoga uwięziła oficerów i wywiesiła czerwoną flagę. Do rebelii dołączyły kolejne stacjonowane w tej bazie okręty. Domagano się zakończenia wojny i poprawy warunków socjalno-bytowych załóg. Gdy do Kotoru przybyły jednostki 3 dywizjonu pancerników (Erzherzog Ferdinand Max oraz Erzherzog Friedrich), bunt został stłumiony tym łatwiej, że jego przywódca, bosmanmat Franz Rasch, zbiegł wodnosamolotem do Włoch ${ }^{29}$. Konsekwencją buntu we flocie była dymisja jej dowódcy, admirała Maximiliana Njegovana, którego cesarz odwołał 1 marca 1918 roku, przenosząc w stan spoczynku. Na jego miejsce powołany został Miklos Horthy, awansowany jednocześnie do stopnia kontradmirała. Cesarza Karola i nowego dowódcę floty lączyły bliskie związki. Horthy - jako adiutant Franciszka Józefa, był bodaj jedynym spoza królewskich rodów gościem na ślubie ówczesnego arcyksięcia Karola z Zytą Burbońską. Cesarz wysoko cenił nie tylko umiejętności dowódcze admirała, ale także jego przywiązanie do porządku i dyscypliny, wreszcie troskę o warunki bytowe załóg okrętów, którymi dotychczas dowodził. Przed objęciem komendy nad flotą dowodził pancernikiem Prinz Eugen, na którym w czasie lutowych buntów nie doszło do żadnych ekscesów ${ }^{30}$. Nowy dowódca floty energicznie przystąpił do działania. Mając świadomość, że bezczynność sprzyja rozluźnieniu dyscypliny, ze wszystkiego tego faktu konsekwencjami zaplanował szeroko zakrojoną operację przeciw blokadzie cieśniny Otranto. Admirał Horthy wyznaczył do tego przedsięwzięcia największe okręty cesarskiej i królewskiej marynarki drednoty Szent István oraz Tegetthoff. Nocą z 8 na 9 czerwca 1918 roku opuściły one Pulę i udały się na południe. Po drodze do zespołu miały dołączyć krążowniki. Na wysokości Premudy o świcie 10 czerwca 1918 roku zespół został dostrzeżony przez dwa włoskie ścigacze torpedowe $M A S 15$ oraz MAS 21. Przy dość biernej postawie okrętów eskorty włoskie jednostki wykonały atak torpedowy. Podwodne pociski trafiły pancernik Szent István, który po trzech godzinach walki jego załogi o uratowanie okrętu zatonął. W tej sytuacji admirał Horthy operację odwołał, bowiem zniknął jej najważniejszy atut, jakim miało być zaskoczenie przeciwnika ${ }^{31}$. Było to ostatnie wyjście trzonu floty habsburskiej w morze.

\footnotetext{
${ }^{28}$ R. Nyppen, Austro-Hungarian Battleships 1914-1918, Oxford 2012, s. 38.

${ }^{29}$ S. Loidl, ,Zweiundhalb Tage waren wir frei”. Zur literarischen und politischen Rezeption des Matrosenaufstand in Cattaro, Jahrbuch für Forschungen zur Geschichte der Arbeiterbewegung, Jahrgang 2014, Nr III, s. $131-152$.

${ }^{30}$ T. Sakmyster, Miklos Horthy..., s. 22.

${ }^{31}$ A. Sokol, Seemacht Österreich. Die kaiserliche und königliche Kriegsmarine 1382-1918, Wien 1982, s. $127-131$.
} 
Niebawem wydarzenia polityczne mające miejsce w dualistycznej monarchii przyćmiły rozwój sytuacji na frontach, także wojny morskiej. Narody monarchii nie chciały już dalej egzystować, jak pisał nieodżałowanej pamięci Henryk Wereszycki - ,pod habsburskim berłem”. Wysiłki elit politycznych Wiednia i Budapesztu, by ratować wielonarodowe państwo, spełzły na niczym. Flota jako element sił zbrojnych państwa Habsburgów była skazana na zagładę wraz z nim. 28 października wraz z proklamowaniem państwa Czechów i Słowaków oraz królestwa SHS Słowian Południowych naddunajska monarchia przeszła do historii. I właśnie w ręce Królestwa Serbów, Chorwatów i Słoweńców władze wiedeńskie zdecydowały się przekazać flotę. Dnia 31 października 1918 roku na pancerniku Viribus Unitis po raz ostatni spuszczono austro-węgierską banderę. Wiceadmirał Miklos Horthy, żegnany z honorami - po raz ostatni opuścił swój flagowy okręt, który przejął od niego dowódca floty nowego państwa, komandor Janko Vuković de Podkapelski. Następnego dnia dwaj marynarze z włoskiej jednostki specjalnej podłożyli pod flagowiec marynarki SHS ładunek wybuchowy, którego eksplozja posłała Viribus Unitis na dno. Zginęło na nim 400 oficerów i marynarzy, łącznie z komandorem Podkapelskim ${ }^{32}$. Zagłada okrętu, mającego w nazwie motto panowania Franciszka Józefa, była wymownym podzwonnym konającego państwa Habsburgów. Strona włoska tłumaczyła się, że nic nie wiedziała o zmianie bandery na pancerniku i innych okrętach. Jednak tego rodzaju wyjaśnienia trudno uznać za wiarygodne. Władze w Rzymie robiły wszystko, by flota pozostała po państwie Habsburgów nie została przejęta przez siły zbrojne królestwa SHS, z którym Italię dzieliły liczne spory terytorialne. Spolegliwi sojusznicy brytyjscy i francuscy przystali na włoskie żądania. Włosi otrzymali ekstra premie za wiarołomstwo w 1915 roku, bo przecież nie za męstwo swych żołnierzy czy talenty dowódcze admirałów i generałów. Ostatecznie c. i k. flotę podzielono między zwycięskie mocarstwa, które otrzymały największe okręty. Królewska flota SHS dostała ostatecznie tylko kilkanaście mniejszych jednostek, jak torpedowce, trałowce oraz monitory rzeczne ${ }^{33}$.

Flotylle rzeczne Republiki Austrii i Królestwa Węgierskiego po traktatach pokojowych z Saint-Germain-en-Laye i Trianon ograniczono do kilku niewielkich okrętów. Tradycje c. i k. floty po anszlusie Austrii w 1938 roku kontynuował wcielony w 1940 roku do służby ciężki krążownik Prinz Eugen. Okręt ten początkowo otrzymał imię admirała Wilhelma Tegetthoffa, jednak ze względu na włoskiego sojusznika, Berlin zmienił nazwę na mniej kontrowersyjnego dla Rzymu dowódcę doby antytureckiej rekonkwisty. W wodowaniu Prinz Eugen na pochylni kilońskiej stoczni uczestniczył w 1938 roku regent Węgier, admirał Horthy, którego małżonka Magda była matką chrzestną okrętu. Na krążowniku podnoszono w rocznice ważnych wydarzeń dla historii c. i k. floty jej banderę wojenną, która na co dzień zdobiła salon dowódcy okrętu. Duch austro-węgierskiej floty okazał się szczęśliwy. Prinz Eugen był jedynym dużym okrętem niemieckiej Kriegsmarine, który przetrwał II wojnę światową ${ }^{34}$.

$\mathrm{Na}$ koniec warto wspomnieć, że c.i k. flota była dostarczycielką kadr oficerskich i podoficerskich dla tworzącej się od listopada 1918 roku Polskiej Marynarki Wojennej. Jeden z jej współtwórców, komandor Bogumił Nowotny był bohaterem działań wojennych

${ }^{32}$ A. Samek, Flota, której już nie ma..., s. 136.

${ }^{33}$ M. Franz, Burza nad Morzem Śródziemnym, t. 1. Burza się rozpoczyna, Oświęcim 2016, s. 174.

${ }^{34}$ R. Kochnowski, Niemieckie działania krqżownicze 1939-1942, Tarnowskie Góry-Zabrze 2015, s. $223-224$. 
na Adriatyku w latach 1915-1918. Nieco młodszy od niego, pochodzący z Krakowa Karol Korytowski był szefem sztabu Kierownictwa Marynarki Wojennej na emigracji w latach 1939-1945 i pod koniec II wojny światowej został awansowany do rangi kontradmirała. Pierwszym wojennym dowódcą ORP Błyskawica był komandor porucznik Włodzimierz Kodrębski, a komandor porucznik Henryk Eibel dowodził niszczycielem ORP Garland, płynącym w eskorcie konwoju PQ-16 w słynnym (i bardzo krwawym) rejsie do Murmańska. Wszyscy oni byli absolwentami Akademii Marynarki w Fiume. Do tego grona należałoby dodać co najmniej kilkunastu jeszcze oficerów i kilkudziesięciu podoficerów, bez których budowa Marynarki Wojennej II RP byłaby znacznie trudniejsza, o ile w ogóle możliwa ${ }^{35}$.

\section{Bibliografia}

Monografie

Csonkaréti K., Marynarka wojenna Austro-Węgier w I wojnie światowej 1914-1918, Kraków 2004.

Donko W. M., Brief History of the Austrian Navy, Berlin 2012.

Halpern P. G.,Österreich - Ungarns Großadmiral 1913-1917, Graz-Wien-Köln 1998.

Rauchensteiner M., Der erste Weltkrieg und das Ende der Habsburgermonarchie 1914-1918, Wien 2013.

Sakmyster T., Miklos Horthy, Wien 2009.

Samek A., Flota, której już nie ma. Powstanie, rozwój i działania marynarki monarchii habsburskiej, Kraków 2011.

Sokol A.,The imperial and Royal Austro-Hungarian Navy, Annapolis 1968.

Artykuły

Broucek P., Njegovan Maximilian, [w:] Österreichisches Biographisches Lexikon, Bd. 7, Wien 1978.

Broucek P., Montecuccoli Rudolfo, [w:] Neue Deutsche Biographie, Berlin 1997.

Freivogel Z., Okrety liniowe typu „,Tegetthoff”,, „Okręty Wojenne”, nr specjalny 27,Tarnowskie Góry 2009.

Kochnowski R., Flota austro-wegierska w przededniu I wojny światowej, [w:] Od Port Artur do Port Stanley. Z dziejów konfliktów morskich w XX stuleciu, red. R. Kochnowski i J. Jastrzębski, Oświęcim 2016.

Roman Kochnowski, prof. Uniwersytetu Pedagogicznego w Krakowie, jest absolwentem kierunku nauki polityczne na Uniwersytecie Śląskim. W 1989 roku uzyskał tamże doktorat, a w 2002 roku habilitację. Obecnie kieruje Katedrą Konfliktów Zbrojnych i Społecznych w Instytucie Nauk o Bezpieczeństwie na Wydziale Politologii Uniwersytetu Pedagogicznego w Krakowie. Na macierzystym Wydziale od 2017 roku pełni funkcję prodziekana ds. nauki. Jego zainteresowania naukowe koncentrują się wokół militarnych oraz politycznych dziejów Austrii i Niemiec w XX stuleciu. Jest promotorem 6 pomyślnie zakończonych doktoratów, opublikował 7 monografii naukowych oraz ponad 80 artykułów naukowych i popularnonaukowych.

${ }^{35}$ R. Kochnowski, Wplyw tradycji Kaiserliche Marine, Kaiserliche und Königliche Marine oraz Wojennomorskowo Fłota na genezę i rozwój Marynarki Wojennej II RP, [w:] Między polityka, historiq a pamięcia historycznq: Studia z dziejów Polski okresu porozbiorowego, red. W. Lazuga i S. Paczos, Poznań 2015, s. 311 i nast. 